\title{
Effect of dexamethasone on IL-2 and IL-3 production by mononuclear cells in neonates and adults
}

\author{
Hanna Bessler, Racheli Straussberg, Nina Gurary, Doron Aloni, Lea Sirota
}

\begin{abstract}
The effect of dexamethasone on interleukin 2 (IL-2) and interleukin 3 (IL-3) production by mononuclear cells in preterm and term infants and adults was evaluated. The capacity of mononuclear cells to produce these cytokines, in preterm infants with bronchopulmonary dysplasia (BPD) and treated with dexamethasone, was compared with that before treatment.
\end{abstract}

Twenty six preterm and 36 term neonates and 24 healthy adults were included in the study. Mononuclear cells isolated from neonatal cord blood (CBMC) and adult peripheral blood (PBMC) were stimulated with phytohaemagglutinin (PHA) in the absence or presence of dexamethasone at concentrations between $10^{-8} \mathrm{M}$ and $10^{-5} \mathrm{M}$. IL-2 and IL-3 activities in the supernatant fluids were tested using bioassays. The in vivo effect of the drug on the production of these cytokines by PBMC in 10 preterms was determined before and 24 hours after dexamethasone administration (0.5 mg/kg/day).

The production of both cytokines was inhibited in a dose dependent manner. A difference in the sensitivity of mononuclear cells to the inhibitory effect of the drug was found between neonatal cord blood cells and adult PBMC, the former being more sensitive. PBMC from preterm infants treated with dexamethasone for BPD produced significantly less IL-2 and IL-3 as early as 24 hours after the initiation of the treatment $(43 \%$ and $31 \%$; $\mathbf{P}<0.05$, respectively).

It is concluded that mononuclear cells from preterm and term neonates are more sensitive to the inhibitory effect of dexamethasone on IL-2 and IL-3 production.

(Arch Dis Child 1996;75:F197-F201)

Keywords: dexamethasone, cytokines, peripheral blood mononuclear cells, bronchopulmonary dysplasia, cord blood.

Treatment with dexamethasone $0.5 \mathrm{mg} / \mathrm{kg} /$ day ${ }^{1-3}$ improves the pulmonary compliance and resistance of mechanically ventilated neonates with bronchopulmonary dysplasia (BPD) within 12 hours. ${ }^{4}$ Prolonged treatment with the drug, however, may be associated with a high rate of potentially lethal infections.
Pharmacological doses of glucocorticosteroids suppress a wide variety of non-specific inflammatory responses and specific immunological processes. ${ }^{5}$ Corticosteroids interfere with several activation events, as well as with the $T$ cell proliferative response induced by antigens and mitogens. ${ }^{67}$ Recent studies have shown that dexamethasone inhibits phytohaemagglutinin (PHA) induced mRNA accumulation for interleukin 2 (IL-2) and IL-2 receptors (IL2R) ${ }^{6-9}$ Kavelaars et al reported in 1995 that neonatal cells are more sensitive to the inhibitory effect of dexamethasone on the proliferative response than adult cells. ${ }^{10}$ This difference in sensitivity was not related to the affinity and capacity of binding labelled dexamethasone. ${ }^{10}$

In our previous study we showed differences in the kinetics of IL-2 production and/or its absorption between neonates and adults. ${ }^{11}$ Furthermore, mRNA for IL-2R could not be detected in the cells of preterm neonates, whereas its concentration in lymphocytes from term infants was similar to that observed in adults. These results suggest a functional difference between the lymphocytes in neonates and adults, as well as between preterm and term neonates.

IL-2 and interleukin 3 (IL-3) are secreted from PHA activated cultures. IL-3 elicits a variety of biological activities in vitro depending on the type of target cells. In addition to its action on myeloid lineage cells, IL-3 promotes pro-B cell growth ${ }^{12}$ and induces $\mathrm{T}$ cell receptor $\gamma$ transcription, ${ }^{13}$ indicating a role for IL-3 in the growth and differentiation of lymphoid lineage cells.

Preterm neonates are more susceptible to infections than adults because of the immaturity of their immune system and the invasive treatment they often receive. Furthermore, preterm infants with BPD are treated with dexamethasone, which suppresses immune function in adults. We therefore aimed to compare the effect of dexamethasone on IL-2 and IL-3 production by mononuclear cells in preterm neonates, term infants, and adults. The capacity of mononuclear cells from preterms with BPD to produce these cytokines was also tested before and after administration of the drug.

\section{Methods}

Twenty six preterm neonates aged $26-32$ weeks (mean (SD) 29 (2.1) weeks) with a mean (SD) birthweight of 1250 (260) $\mathrm{g}$ and 36 term 
neonates spontaneously delivered with a mean (SD) birthweight of 3020 (456) g (appropriate for gestational age) were included in the study. The mothers of the preterm infants did not receive steroid treatment before delivery. The gestational age was calculated from the first day of the mother's last menstrual bleeding before pregnancy, and was confirmed by the Dobowitz test. Twenty four healthy adults (blood bank donors) aged 25-45 years (mean (SD) 37(6.2) years) served as controls. The study was approved by the Helsinki Committee of the Hospital.

Blood was withdrawn from the umbilical cord of the preterm and term neonates immediately following ligation of the cord, from the neonatal side of the placenta. Mononuclear cells were isolated from the cord blood (CBMC) of preterm and term neonates and the peripheral blood (PBMC) of healthy volunteers using Ficoll Hypaque gradient centrifugation. Mononuclear cells were suspended in RPMI-1640 medium containing $1 \%$ penicillin, streptomycin, and nystatin, and supplemented with $10 \%$ fetal calf serum (FCS-M).

PBMC $\left(1.5 \times 10^{6}\right)$ suspended in $1 \mathrm{ml} \mathrm{FCS}-\mathrm{M}$ were incubated in the presence of $1 \%$ phytohaemagglutinin (PHA-M). Dexamethasone was added at the start of the cultures at concentrations ranging between $10^{-8} \mathrm{M}$ and $10^{-5} \mathrm{M}$. Cultures incubated in the absence of dexamethasone served as controls. Culture media were collected at 48 hours, the cells were removed by centrifugation, and the supernatant fluids were kept at $-20^{\circ} \mathrm{C}$ until assayed for IL-2 or IL-3 activities.

IL-2 activity in the supernatant fluids was determined using the IL-2 dependent cell line CTLL 2, as described before. ${ }^{14}$ IL-3 activity in the supernatant fluids was evaluated using the IL-3 responsive (GM-CSF unresponsive) 32 D-cl-23 cell line, as described before. ${ }^{15}$ Briefly, 50000 CTLL 2 cells (for IL-2) or 32-D-cl-23 cells (for IL-3) were incubated for 48 hours with samples of supernatant fluids (four serial dilutions, each in triplicate) in 96 flatbottomed micro titre plates. $3 \mathrm{H}-\mathrm{TdR}$ (methyl-

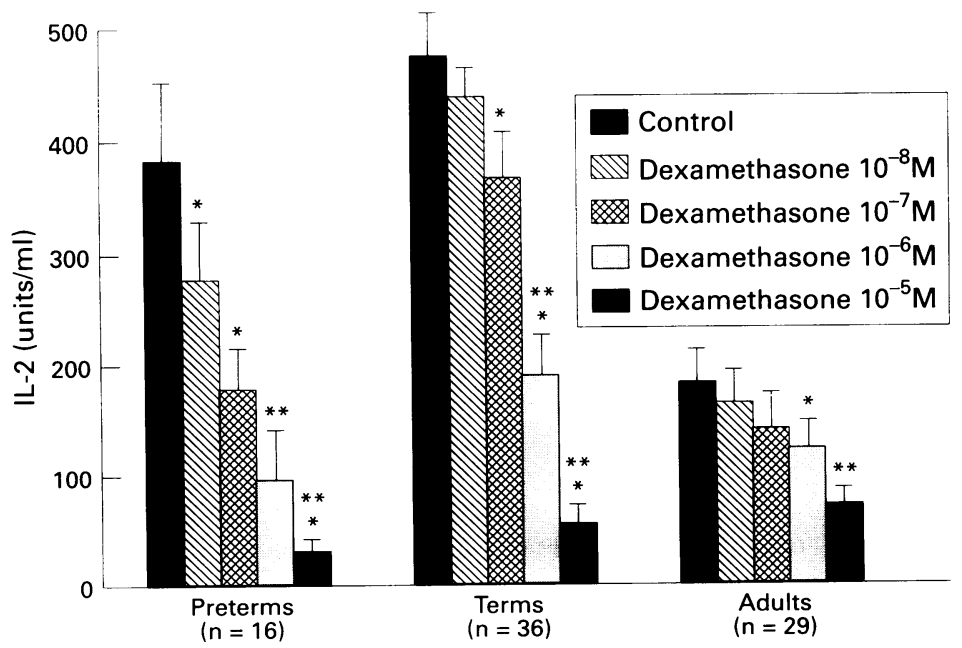

Figure 1 Effect of dexamethasone on IL-2 production by CBMC from preterm and term neonates and adult PBMC. Dexamethasone was added at concentrations indicated. Bars represent $S E M$. Asterisks represent significant difference from the control value ( ${ }^{\star} P<0.05$;

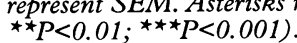

Table 1 Effect of dexamethasone on $I L-2$ and $I L-3$ bioassays

\begin{tabular}{lll}
\hline Dexamethasone & IL-2 units/ml & IL-3 units/ml \\
\hline 0 & $935(63)$ & $90.6(12.3)$ \\
$10^{-7} \mathrm{M}$ & $947(57)$ & $117.0(13.5)$ \\
$10^{-6} \mathrm{M}$ & $933(92)$ & $115.1(10.7)$ \\
$10^{-5} \mathrm{M}$ & $1048(71)$ & $81.5(11.9)$ \\
\hline
\end{tabular}

Values are expressed as mean (SE) of five experiments, each set in triplicate.

3H-thymidine, $5 \mathrm{Ci} / \mathrm{mmol}$; Rotem Industries LTD, Beer-Sheva, Israel) was added ( $0.5 \mu \mathrm{Ci} /$ well) 18 hours before harvesting. The results were calculated as units $/ \mathrm{ml}$ compared with IL-2 or IL-3 containing preparations (supernatant fluids from concanavalin A-stimulated rat splenocytes or WEHI-3 cell line, respectively) which were arbitrarily regarded as 1000 units. These standard curves are linear at a certain range of concentrations, and standard curves are obtained with recombinant cytokines.

Dexamethasone was added to FCS-M containing $1 \%$ phytohaemagglutinin at concentrations ranging between $10^{-8} \mathrm{M}$ and $10^{-5} \mathrm{M}$. Cultures incubated in the absence of dexamethasone served as controls. Culture media were collected at 48 hours, and were kept at $-20^{\circ} \mathrm{C}$ until assayed. Control samples and those with dexamethasone were added to standard IL-2 or IL-3 containing supernatant fluids, and the cytokine activities in these supernatant fluids were determined using the bioassays, as described above. Cytokine activity in the presence of dexamethasone was compared with that in its absence.

Dexamethasone was given to 10 mechanically ventilated infants with moderate to severe BPD. Their mean (SD) gestational age was 27 (2.7) weeks, and their mean (SD) birthweight was $850(280) \mathrm{g}$. The protocol used was 0.5 $\mathrm{mg} / \mathrm{kg} /$ day of dexamethasone over 12 hours for 3 days, decreased to $0.3 \mathrm{mg} / \mathrm{kg} /$ day for 3 days, after which the drug was reduced by $20 \%$ every 3 days. Blood samples were collected from the preterm infants before and 24 hours after the initiation of dexamethasone treatment. PBMC were isolated and incubated for the production of IL-2 and IL-3, as described above. At the end of the incubation period supernatant fluids were collected and stored at $-20{ }^{\circ} \mathrm{C}$ until tested for cytokine activity.

Statistical analysis was performed using the one way analysis of variance (ANOVA) or paired $t$ test. The results were expressed as mean \pm SEM.

\section{Results}

The addition of dexamethasone in concentrations used in the current study $\left(10^{-8}\right.$ to $\left.10^{-5} \mathrm{M}\right)$ to supernatant fluids containing IL-2 or IL-3 had no effect on the cytokine activities detected by the bioassays (table 1 )

The viability of PBMC from preterm and term infants and adults (five in each group) incubated for 48 hours without or with PHA in the absence or presence of the various concentrations of dexamethasone $\left(10^{-8}\right.$ to $\left.10^{-5} \mathrm{M}\right)$ was determined by trypan blue dye exclusion. Under these conditions dexamethasone did not alter cell viability (over $98 \%$ ). 


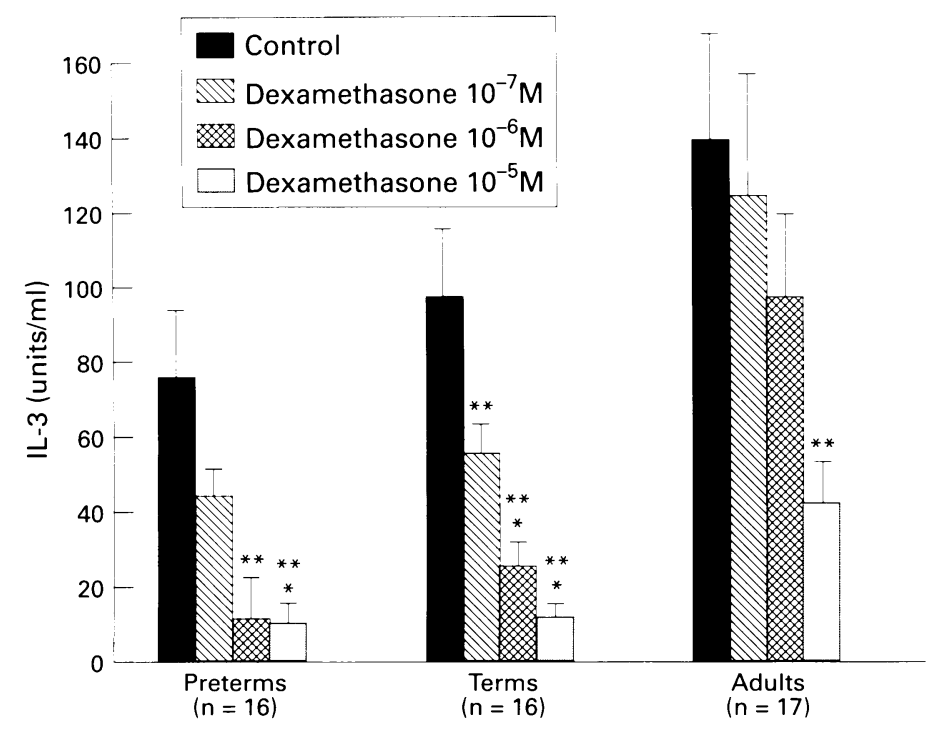

Figure 2 Effect of dexamethasone on IL-3 production by CBMC from preterm and term neonates and from adult PBMC. Dexamethasone was added at the start of cultures at concentrations indicated. Bars represent SEM. Asterisks represent significant difference from the control value $\left({ }^{\star} P<0.01 ;{ }^{\star *} P<0.001\right)$.

In the presence of dexamethasone at concentrations ranging between $10^{-8}$ and $10^{-5} \mathrm{M}$, a dose dependent inhibition of IL-2 production was observed (fig 1), $(\mathrm{F}(4,67)=6.08, \mathrm{P}<0.01$ for preterm infants; $F(4,127)=5.43, P<0.01$ for term infants; $F(4,85)=3.8, P<0.01$ for adults). At a concentration as low as $10^{-8} \mathrm{M}$, a significantly decreased IL-2 production $(23 \%$, $\mathrm{P}<0.01)$ by CBMC from preterms was evident; the mononuclear cells from term infants or adults were not affected significantly. IL-2 activity in the supernatant fluids of preterm and term CBMC incubated with $10^{-7} \mathrm{M}, 10^{-6} \mathrm{M}$, and $10^{-5} \mathrm{M}$ dexamethasone was suppressed by $53 \%, 74 \%$, and $92 \%$, and by $23 \%, 60 \%$, and $88 \%$, respectively $(\mathrm{P}<0.05) \quad(\mathrm{P}<0.01)$ $(\mathrm{P}<0.001)$. In the supernatant fluids of adult PBMC incubated in the presence of $10^{-6} \mathrm{M}$ and $10^{-5} \mathrm{M}$, IL-2 activity was significantly reduced by $32 \%(P<0.05)$ and $60 \%(P<0.01)$, respectively (fig 1). IL-2 activity detected in the supernatant fluids of adult PBMC incubated in the absence or presence of lower concentra-

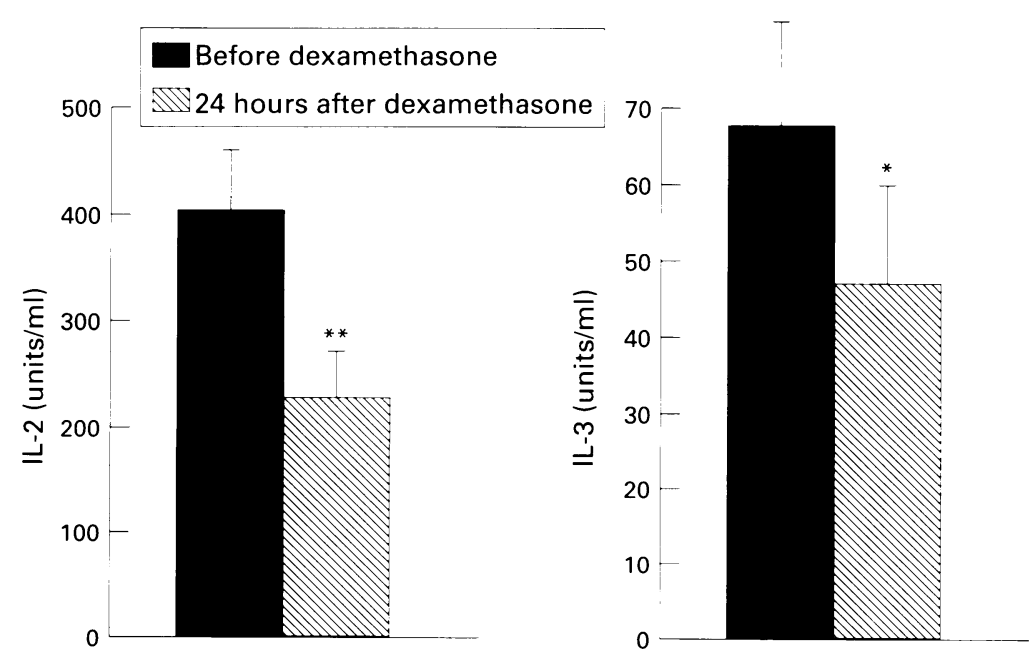

Figure 3 IL-2 and IL-3 production by PBMC from preterm neonates treated with dexamethasone. Each column represents the mean of 10 blood samples; bars $=S E M$; asterisks indicate significant difference from the values before treatment $\left({ }^{\star} P<0.05\right.$; $\left.{ }^{\star} * P<0.01\right)$. tions of dexamethasone $\left(10^{-8} \mathrm{M}\right.$ and $\left.10^{-7} \mathrm{M}\right)$ did not differ substantially (fig 1 ). The differences in sensitivity to the inhibitory effect of dexamethasone on IL-2 production were significant at the following concentrations: adults $v s$ terms at $10^{-5} \mathrm{M},(\mathrm{P}<0.001)$; adults vs preterms at $10^{-5} \mathrm{M}, 10^{-6} \mathrm{M}$, and $10^{-7} \mathrm{M}(\mathrm{P}<0.001, \mathrm{P}<0.001$, $\mathrm{P}<0.01)$; terms vs preterms at $10^{-6} \mathrm{M}(\mathrm{P}<0.05)$.

In the presence of dexamethasone at concentrations ranging between $10^{-7}$ and $10^{-5} \mathrm{M}$, IL-3 production was inhibited in a dose dependent manner (fig 2) $(\mathrm{F}(3,64)=4.05$, $P<0.05$ for preterm infants; $F(3,111)=7.82)$, $\mathrm{P}<0.01$ for term infants; $\mathrm{F}(3,62)=3.63$, $\mathrm{P}<0.05$ for adults). IL-3 activity in the supernatant fluids of preterm and term CBMC incubated with $10^{-7} \mathrm{M}, 10^{-6} \mathrm{M}$ and $10^{-5} \mathrm{M}$ dexamethasone was significantly suppressed by $48 \%, 74 \%$, and $85 \%$, and by $32 \%, 60 \%$, and $77 \%$, respectively $(\mathrm{P}<0.05, \quad \mathrm{P}<0.01$, and $\mathrm{P}<0.001)$. In the supernatant fluids of adult PBMC incubated in the presence of $10^{-6} \mathrm{M}$ and $10^{-5} \mathrm{M}$, IL-3 activity was significantly reduced by $48 \%$ and $57 \%$, respectively $(\mathrm{P}<0.05$ and $\mathrm{P}<0.01$ ), whereas incubation with $10^{-7} \mathrm{M}$ dexamethasone did not inhibit affect IL-3 production (fig 2). The differences in sensitivity to the inhibitory effect of dexamethasone on IL-3 production were significant at the following concentrations: adults $v s$ terms at $10^{-6} \mathrm{M}$ $(\mathrm{P}<0.03)$; adults vs preterms at $10^{-5} \mathrm{M}, 10^{-6} \mathrm{M}$, and $10^{-7} \mathrm{M}(\mathrm{P}<0.05)$; terms vs preterms at $10^{-6} \mathrm{M}(\mathrm{P}<0.05)$.

The in vivo effect of dexamethasone on IL-2 and IL-3 production is shown in fig 3 . IL-2 production was reduced by $43 \%(\mathrm{P}<0.01)$ and that of IL- 3 by $31 \%(P<0.05)$ in the PBMC of preterm infants 24 hours after the initiation of dexamethasone.

\section{Discussion}

This study indicates that the blood mononuclear cells from premature neonates are more sensitive to dexamethasone than those from term neonates. Evidence suggests that the human neonatal immune system differs functionally from that of the adult. This is in part because of the differences found between cord blood cells and adult peripheral blood cells. It is generally accepted that cord blood $\mathrm{T}$ lymphocytes, ${ }^{1617}$ B lymphocytes,${ }^{18}$ monocytes ${ }^{19}$ and dendritic cells ${ }^{20}$ are functionally inferior, or express different levels of certain cell surface antigens compared with the corresponding cells of adults. CBMC also have a unique cytokine profile when compared with PBMC. In this study, the sensitivity of CBMC to the in vitro inhibitory effect of dexamethasone on cytokine production was greater than that of PBMC from adults. Moreover, dexamethasone added to CBMC from preterm and term neonates at pharmacological doses induced maximal IL-2 suppression and moderate IL-3 production, whereas adult PBMC were less affected. Our results agree with those of Kavelaars et al, who showed that blood mononuclear cells or purified $T$ cells from term neonates are more sensitive than adult cells to dexamethasone with regard to proliferation and IL-2R expression. ${ }^{10}$ The effect of dexam- 
ethasone was similar on purified $T$ cells and PBMC and did not reflect differences in expression of glucocorticoid receptors. ${ }^{10}$ As the inhibitory effect of dexamethasone on cells from neonates, but not from adults, could be overcome by exogenous IL-2, it was suggested that the primary target of dexamethasone in neonatal cells was inhibition of IL-2 production. Our observations confirm this suggestion. The assumption that dexamethasone may interfere with the binding of these cytokines to the specific receptors on the target cells has been excluded as the addition of the drug to IL-2 or IL-3 containing supernatant fluids at concentrations similar to those used in the present study had no effect on their activities, as tested in the bioassays.

Dexamethasone is a synthetic corticosteroid with numerous pharmacological effects, widely used in the neonatal units for the prevention and treatment of BPD. Previous studies have shown that pharmacological doses of glucocorticosteroids exert a profound suppressive effects on the inflammatory and immune responses. ${ }^{5}$ Corticosteroids interfere with several activation events and with the $T$ cell proliferative response induced by antigens and mitogens, ${ }^{67}$ including the production of IL-2 and the expression of IL-2R. ${ }^{6-9}$ The precise mechanism by which corticosteroids exert their effect on the immune system is not yet known. However, inhibition of cytokine production ${ }^{821}$ via blockade of cytokine gene transcription -for example, IL-1, IL-2, IL-6 and $\gamma \mathrm{IFN}{ }^{22-25}$ and/or decreasing the stability of cytokine mRNA $^{62326}$ has been reported. Recently it has been shown that dexamethasone inhibits the nuclear transcription and accumulation of IL-2, whereas its effect on IL-2R is post transcriptional ${ }^{27}$ and requires suprapharmacological concentrations. It has therefore been suggested that the inhibitory effect of dexamethasone is probably indirect, resulting from decreased IL-2 production. ${ }^{27}$

In our previous study we have found different kinetics for IL-2 production and/or its absorption in neonates and adults. ${ }^{11}$ Furthermore, mRNA for IL-2R could not be detected in the cells of preterm neonates, whereas the concentration found in mononuclear cells from term infants was similar to that in adults, suggesting maturational differences. It is conceivable that the various degrees of sensitivity to the inhibitory effect of dexamethasone on cytokine secretion by cells of preterm and term infants and adults that we observed could be attributed to these maturational differences.

Significantly decreased IL-2 and IL-3 secretion by PBMC from preterm neonates treated with dexamethasone $(0.5 \mathrm{mg} / \mathrm{kg} / \mathrm{day})$ was observed 24 hours following treatment. This could be due either to the direct effect of the drug on cytokine producing cells or, alternatively, to the decline in circulating lymphocytes and monocytes observed after administration of a single dose of corticosteroids. ${ }^{28}$ In mice a single dose of dexamethasone induced inhibition of lymphocyte proliferation which was evident within 4 hours of administration of the drug and was maintained for at least 24 hours. ${ }^{29}$ In the murine system, IL- $1 \alpha$, IL-4, IL-6, IL-10 and $\gamma$ IFN concentrations were decreased by low doses of dexamethasone; higher doses were required to inhibit production of IL-2, IL-3, and tumour necrosis factor. $^{29}$

Dexamethasone is the drug of choice for BPD in the neonatal intensive care units. As preterm neonates are more susceptible to infections due to a combination of an immature immune system and intensive treatment, longer periods of dexamethasone treatment may suppress cytokine production and thus may further impair their immune response.

1 Ward RM. The use of therapeutic drugs. In: Avery GB Fletcher MA, MacDonald MG, eds. Neonatology. Pathophysiology and management of the newborn. Philadelphia: J.B physiology and management of the new

2 Harkavy KL, Scanlon JW, Chowdhry PK, Crylack LJ. Dexamethasone therapy for chronic lung disease in ventilatorand oxygen dependent infants: a controlled trial. $\mathcal{F}$ Pediat 1989;115: 979-83

3 Cummings JJ, D'Eugenio DB, Gross SJ. A controlled trial of dexamethasone in preterm infants at high risk for bronchopulmonary

4 Gladstone IM, Ehrenkranz RA, Jacobs HC. Pulmonary function tests and fluid balance in neonates with chronic lung disease during dexamethasone treatment. Pediatrics lung disease during

5 Boumpas DT, Paliogianni F, Anastassiou ED, Balow JE. Glucocorticosteroid action on the immune system: molecular and cellular aspects. Clin Exp Rheumatol 1991; 9 413-23.

6 Arya SK, Wong-Staal F, Gallo RC. Dexamethasone mediated inhibition of human $T$ cell growth factor and gamma-interferon messenger RNA. F Immunol 1984;133: 273-6.

7 Bettens F, Kristensen F, Walker C, Schwulera U, Bonnard GD, de Weck AL. Lymphokine regulation of activated (G1) lymphocytes. II. Glucocorticoid and anti-Tacinduced inhibition of human $\mathrm{T}$ lymphocyte proliferation. $\mathcal{F}$ Immunol 1984;132: 261-5.

8 Gillis S, Crabtree GR, Smith KA. Glucocorticoid-induced inhibition of T cell growth factor production: Effect on mitogen induced lymphocyte proliferation. $f$ Immunol mitogen induced

9 Reed JC, Abidi AH, Alpers JD, Hoover RG, Robb RJ, Nowell PC. Effect of cyclosporin A and dexamethasone on interleukin 2 receptor gene expression. $f$ Immuno 1986;137:150-4.

10 Kavelaars A, Zijlstra J, Bakker JM, Van-Rees EP, Visser GH, Zegers BJ, et al. Increased dexamethasone sensitivity of neonatal leukocytes: different mechanisms of glucocorticoid inhibition of $\mathrm{T}$ cell proliferation in adult and neonatal cells. Eur F Immunol 1995;25:1346-51.

11 Bessler H, Sirota L, Notti I, Milo T, Djaldetti $M$ Interleukin-2 receptor gene expression and interleukin-2 Interleukin-2 receptor gene expression and interleukin-2 Immunol 1993; 93: 479-83.

12 Palacios R, Karasuyama H, Rolink A. Ly1+ Pro-B lymphocyte clones. Phenotype, growth requirements and differentiation in vitro and in vivo. Embo $\mathcal{f} 1987 ; 6$ : 3687 93.

13 Weinstein Y, Morishita K, Cleveland JL, Ihle JN. Interleukin 3 (IL-3) induces transcription from nonrearranged $\mathrm{T}$ cell receptor gamma loci in IL-3-dependent cell lines. $f$ Exp Med 1989;169: 2059-71.

14 Serrate SA, Schulof RS, Leondaridis L, Goldstein AL Sztein MB. Modulation of natural killer cell cytotoxic activity, lymphokine production and interleukin 2 receptor activity, lymphokine production and interleukin 2 receptor 2338-43.

15 Sakakeeny MA, Greenberg JS. Granulopoiesis longevity in continuous bone marrow culture and factor dependen cell line generation: Significant variation among 28 inbred mouse strain ant outbid stocks. FNCI 1982; 68: 305-17.

16 Wilson CB. The ontogeny of $T$ lymphocyte maturation and function. F Pediatr 1991;118: S4-S9.

17 Harris DT, Schumacher MJ, Locascio J, Besencon FJ, Olso GB, Deluca D. Phenotypic and functional immaturity of human umbilical cord blood T lymphocytes. Proc Nat Acad Sci USA 1992;89:10006-10

18 Tucci A, Mouzaki A, James H, Bonnefoy JTY, Zubler RH. Are cord blood B cells functionally mature? Clin Exp Immunol 1991;84:389-94.

19 Taylor S, Bryson YJ. Impaired production of gamma interferon by newborn cells in vitro is due to a functionally immature macrophage. F Immunol 1985;134:1493-7.

20 Hunt DWC, Huppertz HI, Jiang HJ, Petty RE. Studies of Hunt DWC, Huppertz HI, Jiang HJ, Petty RE. Studies of human cord blood dendritic cells: Evider

21 Whal SM, Altman LC, Rosenstreich DL. Inhibition of lymphokine synthesis by glucocorticosteroids. F Immunol phokine synthesis 
22 Knudsen PJ, Dinarello CA, Strom TB. Glucocorticoids inhibit transcriptional and post-transcriptional expression of interleukin 1 in U937 cells. F Immunol 1987; 139: 4129-34.

23 Lee SW, Tsuo PAP, Chan H, Thomas J, Petrie K, Euqui EM. Glucocorticoids selectively inhibit transcription of the interleukin 1 beta gene and decrease the stability of interleukin 1 beta mRNA. Proc Natl Acad Sci USA 1988; 85: 1204-8.

24 Zanker B, Walz G, Wieder KJ, Storm TB. Evidence that glucocorticsteroids block expression of the human interleukin-6 gene by accessory cells. Transplantation 1990; 49:183-5.

25 Almawi WY, Lipman ML, Stevens AC, Zanker B, Hadro ET, Strom TB. Abrogation of glucocorticoid-mediated inhibition of $T$ cell proliferation by the synergistic action of $I L-1, \pi-6$, and IFN-gamma. $f$ Immunol 1991;146: 3523-7.
26 Gessani S, McCandless S, Baglioni C. The glucocorticoid dexamethasone inhibits synthesis of interferon by decreasing the level of its mRNA. F Biol Chem 1988; 263: 7454-7.

27 Boumpas DT, Anastassiou ED, Older SA, Tsokos GC, Nelson DI Balow JE. Dexamethasone inhibits human interson 2 , Balow JE. Dexamether leukin 2 but not interleukin 2 receptor gene expression in vitro at the level of nuclear transcription. $\mathcal{f}$ Clin Invest 1991; 87: 1739-47.

28 Fauci AS, Dale DC. The effect of in vivo hydrocortisone on subpopulation of human lymphocytes. $\mathcal{f}$ Clin Invest 1974; 53: 240-6.

29 Kunica JE, Talle MA, Denhardt GH, Brown M, Price LA, Goldstein G. Immunosuppression by glucocorticoids: inhibition of production of multiple lymphokines by in vivo administraion of dexamethasone. Cell Immunol 1993; 149: 39-49. 